\title{
Particle Size Distribution Effect on Unconfined Compressive Strength of Sand-Slag-Fiber
}

\author{
Hamid Nikraz ${ }^{1}$, Amin Chegenizadeh ${ }^{2}$ \\ ${ }^{1}$ Professor, Department of Civil Engineering, Curtin University of Technology, Kent Street, Bentley, Perth, \\ Western Australia 6102, Australia. h.nikraz@ curtin.edu.au \\ ${ }^{2}$ Senior Lecturer, Department of Civil Engineering, Curtin University of Technology, Kent Street, Bentley, Perth, \\ Western Australia 6102, Australia. amin.chegenizadeh@ curtin.edu.au
}

\begin{abstract}
Particle Size Distribution (PSD) is one of the important factors affecting the behavior of soils. This study in combination of such an effect and soil stabilization. In this study, sand mixed with slag a fiber exposes to UCS testing. The mixture has been stabilized with very high fiber percentage $20 \%$, the slag was varied from $5 \%-15 \%$. The results showed that UCS values changed by PSD variations.
\end{abstract}

Key Words: PSD, Slag, Fiber

\section{INTRODUCTION}

The investigation of the behavior of the soil is one of the important factor in our managing the stresses into a firm ground. Of those literature, readers can be referred to [1-14]. The stress investigation was conducted in different aspect as an example, numerical modelling of stresses and it application in pavement engineering [4], anisotropic matters in [5], liquefaction stresses in [9] or a cyclic one [12].

The fiber application is relevant to this study and being applied in shear, permeability and compressive strength [15-23]. The application of fiber not limited to direct shear testing, compaction, UCS, permeability testing and triaxial testing.

The by- product application such as flyash being investigated in literature and some of them can be access in [24-30]. The usage of fly-ash helps the community not only removed them from land fill but also use them effectively in geo-project. Another popular by-product is slag which being applied in soils in different occasions. [31-34]. The bentonite also being applied to stabilize and being used in cut-off walls [ 35-36].

The further application of tyre is also studied in literature [37-42]. Very limited study has considered a very high fiber dosage along with slag.

This study is a continuation of research in Curtin University. The study is considering effect of slag into fiber-clay compressive strength. This work is continuation of stabilization research on soil in Curtin university.

\section{MATERIALS}

This study aimed to consider the mixture of clay, fiber and cement. The following sections show the used materials:

\subsection{Clay}

Three soils with different PSD curves but all sandy type were selected to do this research. The PSD s are presented in Figure 1.

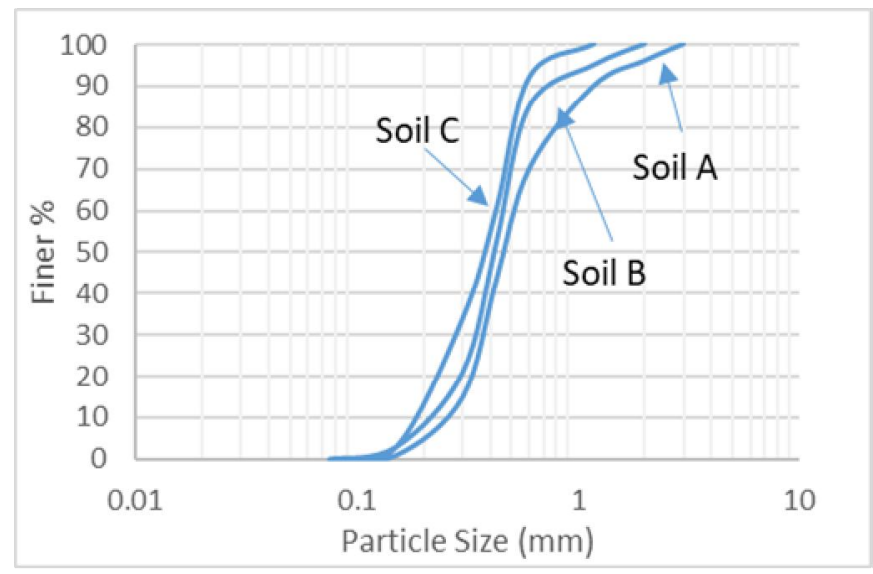

Figure 1: PSD curves of the employed soils

\subsection{Slag}

The slag properties can be found in the table 1. The slag was sourced from Perth supplier.

Table 1: Slag properties

\begin{tabular}{|l|l|}
\hline Item & Characteristics/values \\
\hline pH & 12 \\
\hline Appearance & Grey \\
\hline Specific Gravity & 2.5 \\
\hline
\end{tabular}


Hamid Nikraz et al., International Journal of Emerging Trends in Engineering Research, 8(5), May 2020, 2031 - 2035

\subsection{Fibre}

The fiber was sourced from Western Australia supplier with the width of $0.8 \mathrm{~mm}$ and length of $2 \mathrm{~mm}$.

\subsection{Fillers}

Tyre and fly ash was used as filler at constant $0.5 \%$.

\section{TESTING PLAN}

The compressive strength of mixture was evaluated using the UCS device. First, the mixture were prepared as combination of soil A/Soil B/Soil C and slag and fiber. The slag percentage was varied from 5 to $15 \%$. The fiber had dosage of $20 \%$. The fiber kept constant to reduce the complexity of testing. The UCS testing were planned as presented in Table 2.

Table 2: Testing program utilized in this study

\begin{tabular}{|c|c|c|c|}
\hline Sample ID & Slag (\%) & Soil PSD & $\begin{array}{c}\text { Fiber } \\
(\boldsymbol{\%})\end{array}$ \\
\hline S-5SL-20F & 5 & A,B,C & 20 \\
\hline S-10SL-20F & 10 & A,B,C & 20 \\
\hline S-15SL-20F & 15 & A,B,C & 20 \\
\hline
\end{tabular}

\section{TEST RESULTS}

\subsection{Compaction Results}

Table 3 displays the compaction features of the used mixes. As can be referred, addition of slag (SL) increased the OMC and reduced MDD value of the mixtures. Table 3 represents the values of compaction for soil A. Table 4 indicates the compaction results for soil $\mathrm{B}$. Table 5 shows the results of compaction for soil C.

Table 3: Results of compaction tests for Soil A

\begin{tabular}{|c|l|c|c|}
\hline Sample ID & Slag (\%) & $\begin{array}{c}\text { OMC } \\
(\%)\end{array}$ & $\begin{array}{c}\text { MDD(gr/cm3 } \\
\mathbf{\%}\end{array}$ \\
\hline S-5SL-20F & 5 & 15.1 & 1.63 \\
\hline S-10SL-20F & 10 & 17.3 & 1.58 \\
\hline S-15SL-20F & 15 & 17.6 & 1.52 \\
\hline
\end{tabular}

Table 4: Results of compaction tests for Soil B

\begin{tabular}{|c|c|c|}
\hline Sample ID & OMC (\%) & MDD \\
\hline S-5SL-20F & 14.9 & 1.61 \\
\hline S-10SL-20F & 17.2 & 1.57 \\
\hline S-15SL-20F & 17.5 & 1.5 \\
\hline
\end{tabular}

Table 5: Results of compaction tests for Soil C

\begin{tabular}{|c|c|c|}
\hline Sample ID & OMC (\%) & MDD \\
\hline S-5SL-20F & 14.8 & 1.6 \\
\hline S-10SL-20F & 16.8 & 1.55 \\
\hline S-15SL-20F & 17.4 & 1.49 \\
\hline
\end{tabular}

\subsection{Unconfined Compressive Strength}

The results of UCS tests can be seen for different soils (i.e. soil A,B,C). Figure2 shows the UCS values for Soil A,B, C. The results show the soil A has the highest value of UCS while the soil $\mathrm{C}$ shows the lowest.

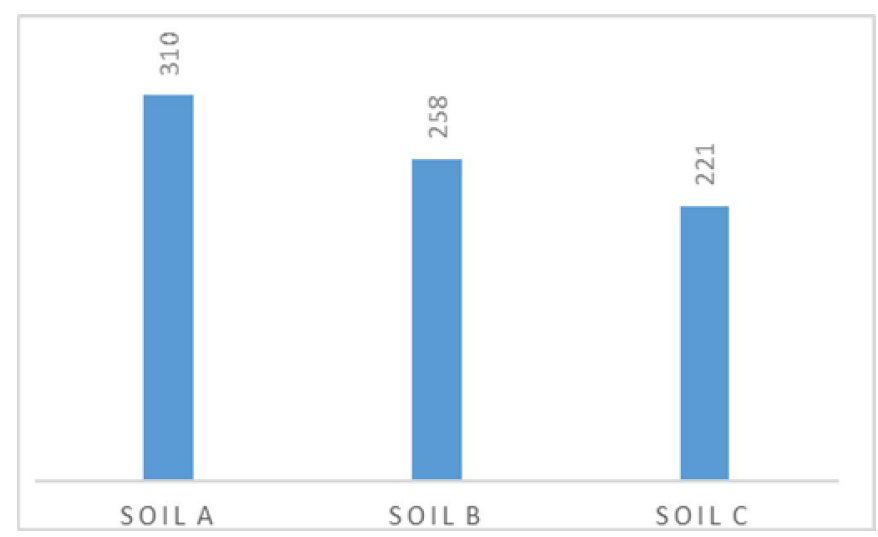

Figure 2: UCS results for sample S-5SL-20F

Figure 3 represents the values of UCS relevant o soil A,B and $\mathrm{C}$ for slag percentage of $10 \%$. Once again, soil A represents the highest UCS values. Same trend of higher value of soil A noticed in slag dosage of $15 \%$ as can be seen in Figure 4.

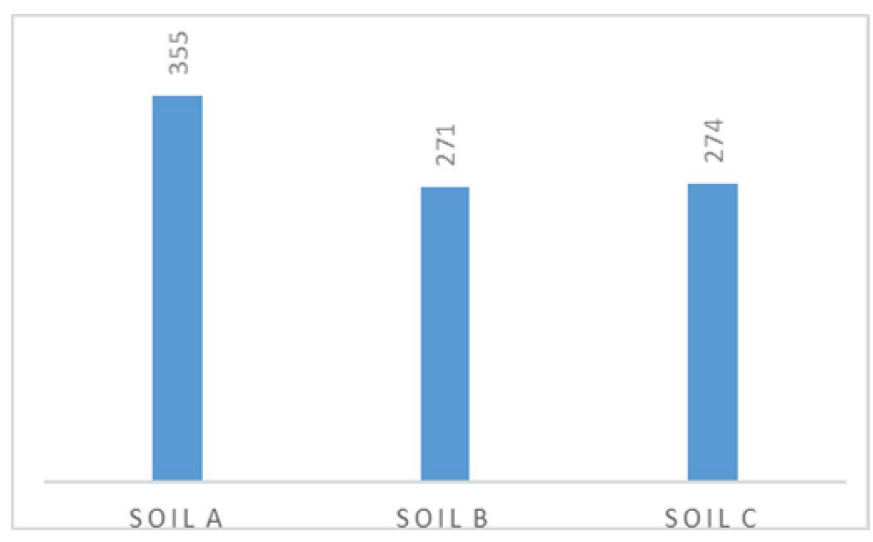

Figure 3: UCS results for sample S-10SL-20F 
Hamid Nikraz et al., International Journal of Emerging Trends in Engineering Research, 8(5), May 2020, 2031 - 2035

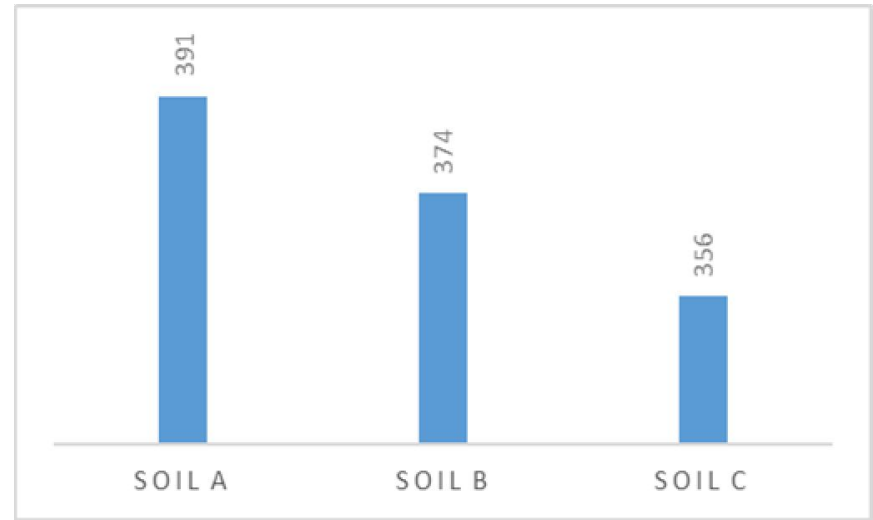

Figure 4: UCS results for sample S-15SL-20F

The slag effect can be seen in Figure in regards to soil A,B,C. Figure 5,6,7 show the effect of slag dosage in UCS values of soil $\mathrm{A}, \mathrm{B}$ and $\mathrm{C}$.

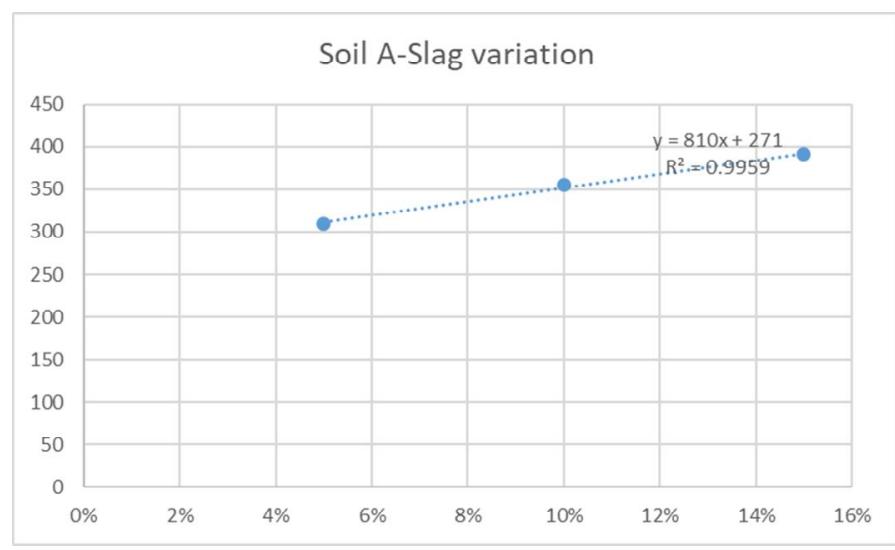

Figure5: UCS results for soil A in different slag dosage

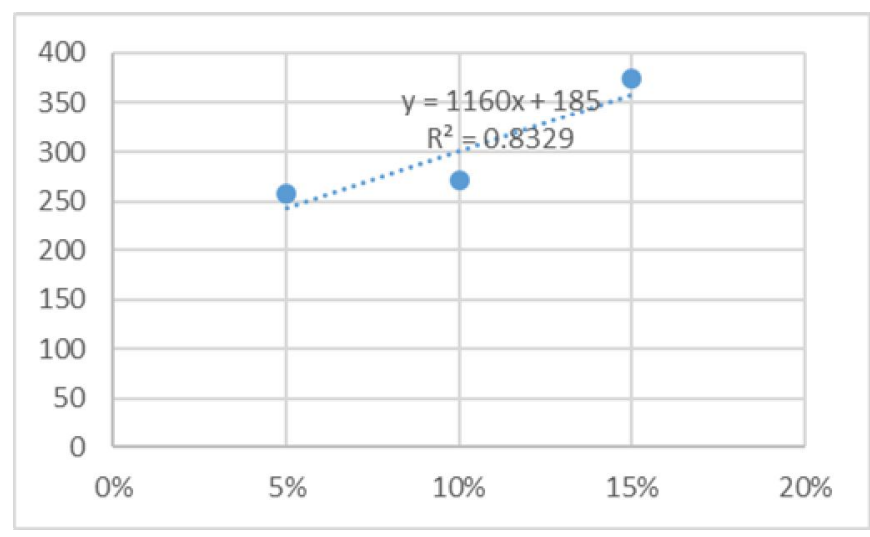

Figure 6: UCS results for soil B in different slag dosage

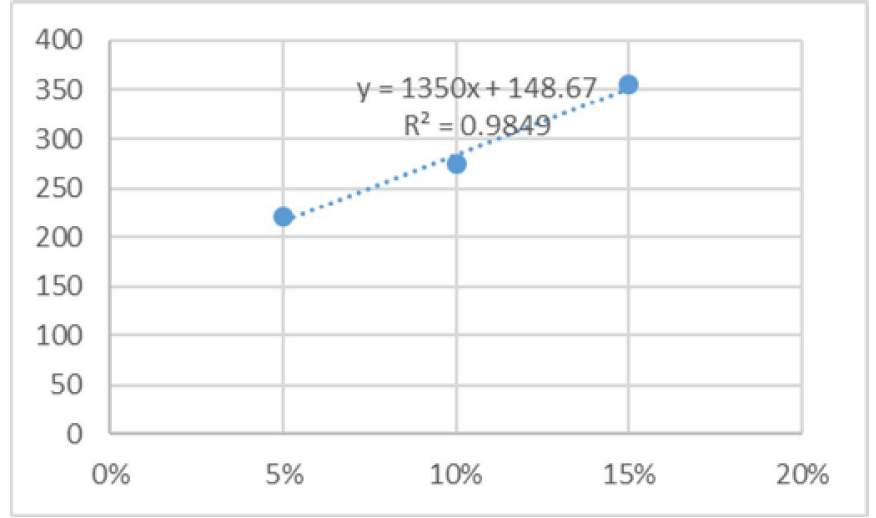

Figure 7: UCS results for soil C in different slag dosage

\section{CONCLUSION}

The conclusion supports that increasing in slag dosage OMC increased and MDD decreased. The soil $\mathrm{C}$ showed less UCS compare to soil A. The soil B also showed less value compare to soil A. The effect of slag on the UCS of mixtures was linear and R-square of the line was very close to 1 .

\section{REFERENCES}

[1] Müller-Vonmoos M, Løken T. The shearing behaviour of clays. Applied clay science. 1989 Jun 1;4(2):125-41. https://doi.org/10.1016/0169-1317(89)90004-5

[2] Biscontin G, Pestana JM. Influence of peripheral velocity on undrained shear strength and deformability characteristics of a bentonite-kaolinite mixture. University of California, Department of Civil Engineering; 1999 Nov.

[3] Wang W, Li N, Zhang F, Zhou A, Chi S. Experimental and mathematical investigations on unconfined compressive behaviour of costal soft soil under complicated freezing processes. Polish Maritime Research. 2016 Dec 1;23(4):112-6. https://doi.org/10.1515/pomr-2016-0077

[4] Chegenizadeh A, Ghadimi B, Nikraz H, Simsek M. A novel two-dimensional approach to modelling functionally graded beams resting on a soil medium. Structural Engineering and Mechanics. 2014;51(5):727-41

[5] Al-Rkaby AHJ, Chegenizadeh A, Nikraz H. Anisotropic strength of large scale geogrid-reinforced sand:experimental study Soils and foundations 2017.57 (4), 557-574 https://doi.org/10.1016/j.sandf.2017.03.008

[6] Alfaro MC, Miura N, Bergado DT. Soil-geogrid reinforcement interaction by pullout and direct shear tests. Geotechnical Testing Journal. 1995 Jun 1;18(2):157-67.

[7]Simac MR, Christopher BR, Bonczkiewicz C. Instrumented field performance of a $6 \mathbf{m}$ geogrid soil wall. InProceedings of the 4'th Int. Conference on 
Hamid Nikraz et al., International Journal of Emerging Trends in Engineering Research, 8(5), May 2020, 2031 - 2035

Geotextiles, Geomembranes and Related Products 1990 Jun (pp. 53-59).

[8]Shihata SA, Baghdadi ZA. Simplified method to assess freeze-thaw durability of soil cement. Journal of materials in civil engineering. 2001 Aug;13(4):243-7.

[9] Keramatikerman M, Chegenizadeh A. Effect of particle shape on monotonic liquefaction: Natural and crushed sand. Experimental Mechanics. 2017 Oct 1;57(8):1341-8.

https://doi.org/10.1007/s11340-017-0313-z

[10] Kalantari B, Huat BB. Peat soil stabilization, using ordinary portland cement, polypropylene fibers, and air curing technique. Electron. J. Geotech. Eng. 2008;13:1-3.

[11]Sabat AK, Nanda RP. Effect of marble dust on strength and durability of Rice husk ash stabilised expansive soil. International Journal of Civil \& Structural Engineering. 2011;1(4):939-48.

[12] Al-rkaby, A.H.J., Chegenizadeh, A., Nikraz, H.R.Cyclic behavior of reinforced sand under principal stress rotation Journal of Rock Mechanics and Geotechnical Engineering 2017 9(4), pp. 585-598

https://doi.org/10.1016/j.jrmge.2017.03.010

[13] Osinubi KJ, Bafyau V, Eberemu AO. Bagasse ash stabilization of lateritic soil. InAppropriate technologies for Environmental Protection in the developing world 2009 (pp. 271-280). Springer, Dordrecht.

[14] Ribeiro D, Néri R, Cardoso R. Influence of water content in the UCS of soil-cement mixtures for different cement dosages. Procedia engineering. 2016 Jan 1;143:59-66. https://doi.org/10.1016/j.proeng.2016.06.008

[15] Chegenizadeh A, Nikraz H. Permeability test on reinforced clayey sand. World Academy of Science, Engineering and Technology. 2011;54:130-3.

[16] Hejazi SM, Sheikhzadeh M, Abtahi SM, Zadhoush A. A simple review of soil reinforcement by using natural and synthetic fibers. Construction and building materials. 2012 May 1;30:100-16.

[17] Chegenizadeh, A. and H. Nikraz, Composite Soil: Fiber Inclusion and Strength, Journal of Advanced Materials Research 2011.1646

[18] Murray JJ, Frost JD, Wang Y. Behavior of a sandy silt reinforced with discontinuous recycled fiber inclusions. Transportation research record. 2000;1714(1):9-17.

https://doi.org/10.3141/1714-02

[19] Chegenizadeh, A., Nikraz, H. Investigation on compaction characteristics of reinforced soil

Advanced Materials Research 2011 261-263, pp. 964-968

[20] Anagnostopoulos CA, Papaliangas TT, Konstantinidis D, Patronis C. Shear strength of sands reinforced with polypropylene fibers. Geotechnical and Geological Engineering. 2013 Apr 1;31(2):401-23.
[21] Chegenizadeh, A., Nikraz, H. Shear test on reinforced clay Advanced Materials Research 2011, 250-253, pp. 3223-3227

[22] Chegenizadeh, A., Nikraz, H. Investigation on strength of fiber reinforced clay Advanced Materials Research 2011.261-263, pp. 957-963.

[23] Kar RK, Pradhan PK, Naik A. Effect of randomly distributed coir fibers on strength characteristics of cohesive soil. The Electronic Journal of Geotechnical Engineering. 2014;19:1567-83.

[24]Kaniraj SR, Havanagi VG. Behavior of cement-stabilized fiber-reinforced fly ash-soil mixtures. Journal of geotechnical and geoenvironmental engineering. 2001 Jul;127(7):574-84..

[25] Prabakar J, Dendorkar N, Morchhale RK. Influence of fly ash on strength behavior of typical soils. Construction and Building Materials. 2004 May 1;18(4):263-7.

https://doi.org/10.1016/j.conbuildmat.2003.11.003

[26] Ahmed AG. Fly ash utilization in soil stabilization. InProceedings of the International Conference on Civil, Biological and Environmental Engineering 2014 May 27 (pp. 76-78).

[27]Keramatikerman $M$, Chegenizadeh A, Nikraz $H$. Experimental study on effect of fly ash on liquefaction resistance of sand Soil Dynamics and Earthquake Engineering,2017. 93, 1-6

[28] Sobhan K, Mashnad M. Mechanical stabilization of cemented soil-fly ash mixtures with recycled plastic strips. Journal of environmental engineering. 2003 Oct;129(10):943-7.

[29] Arulrajah A, Kua T-A, Horpibulsuk S, Phetchuay C, Suksiripattanapong C, Du Y-J. Strength and microstructure evaluation of recycled glass-fly ash geopolymer as low-carbon masonry units. Construction and Building Materials. 2016;114:400-6.

[30] Arezoumandi M, Volz JS. Effect of fly ash eplacement level on the shear strength of high-volume fly ash concrete beams. Journal of cleaner production. 2013 Nov 15;59:120-30. https://doi.org/10.1016/j.jclepro.2013.06.043

[31] He J, Wang XQ, Su Y, Li ZX, Shi XK. Shear strength of stabilized clay treated with soda residue and ground granulated blast furnace slag. Journal of Materials in Civil Engineering. 2019 Mar 1;31(3):06018029.

[32] Sabbar AS, Chegenizadeh A, Nikraz H. Static liquefaction of very loose sand-slag-bentonite mixtures. Soils and Foundations. 2017 Jun 1;57(3):341-56.

https://doi.org/10.1016/j.sandf.2017.05.003

[33] Pathak AK, Pandey V, Murari K, Singh JP. Soil stabilisation using ground granulated blast furnace slag. Int. J. Eng. Res. Appl. 2014 May;4:164-71.

[34] Thomas A, Tripathi RK, Yadu LK. A laboratory investigation of soil stabilization using enzyme and alkali-activated ground granulated blast-furnace slag. Arabian Journal for Science and Engineering. 2018 Oct 1;43(10):5193-202. 
[35] Keramatikerman, M., Chegenizadeh, A., \& Nikraz, H. An investigation into effect of sawdust treatment on permeability and compressibility of soil-bentonite slurry cut-off wall. Journal of Cleaner Production, 2017.162, 1-6.

[36] Chegenizadeh, A., Keramatikerman, M., Dalla Santa, G., $\&$ Nikraz, $\mathrm{H}$. Influence of recycled tyre amendment on the mechanical behaviour of soil-bentonite cut-off walls. Journal of cleaner production, 2018.177, 507-515 https://doi.org/10.1016/j.jclepro.2017.12.268

[37] Chegenizadeh A, Keramatikerman M, Panizza S, Nikraz $\mathrm{H}$. Effect of powdered recycled tire on sulfate resistance of cemented clay. Journal of Materials in Civil Engineering. 2017 Oct 1;29(10):04017160.

[38]Mashiri MS, Vinod JS, Sheikh MN, Tsang HH. Shear strength and dilatancy behaviour of sand-tyre chip mixtures. Soils and Foundations. 2015 Jun 1;55(3):517-28. https://doi.org/10.1016/j.sandf.2015.04.004

[39]Barman P, Singh B. Influence of Tyre Buffings and Cement on Strength Behaviour of Soil-Fly Ash Mixes. International Journal of Geosynthetics and Ground Engineering. 2017 Mar 1;3(1):10.

[40] Vinod JS, Sheikh MN, Mashiri S. Cyclic behaviour of scrap-tyre soil mixtures. InFrontiers in Geotechnical Engineering 2019 (pp. 303-311). Springer, Singapore.

[41]Srivastava A, Pandey S, Rana J. Use of shredded tyre waste in improving the geotechnical properties of expansive black cotton soil. Geomechanics and Geoengineering. 2014 Oct 2;9(4):303-11.

https://doi.org/10.1080/17486025.2014.902121

[42] Signes CH, Garzón-Roca J, Fernández PM, de la Torre ME, Franco RI. Swelling potential reduction of Spanish argillaceous marlstone Facies Tap soil through the addition of crumb rubber particles from scrap tyres. Applied Clay Science. 2016 Nov 1;132:768-73.

https://doi.org/10.1016/j.clay.2016.07.027 